\title{
Social capital and cross-selling within financial holding companies in an emerging economy
}

\author{
Cheng-Min Chuang • Chih-Pin Lin
}

Published online: 9 August 2007

(C) Springer Science + Business Media, LLC 2007

\begin{abstract}
Social capital is the goodwill available to individuals or groups from their network of relationships. It is widely believed that social capital is useful in facilitating and governing hazardous transactions. But how social capital, in the context of a financial holding company (FHC), actually facilitates cross-selling is unknown, especially in an emerging economy. This article maintains that effective cross-selling requires an FHC to first access and accumulate comprehensive and tacit customer-specific knowledge (the "where from" condition) and then share and leverage this knowledge to other applicable business opportunities (the "where to" condition). The role of social capital and embedded ties is found to be critical to this process. Finally, we argue that the major route for the effective cross-selling within an FHC is from the commercial banking division to the underwriting division. Hypotheses are tested on the transactional data collected from Taiwan, and empirical results provide broad support for our arguments.
\end{abstract}

Keywords Social capital · Cross-selling · Financial holding companies · Emerging economies

In many emerging economies in Asia, capital markets are not as efficient as those in developed countries. Recently, many management scholars have maintained that establishing large and diversified business conglomerates based

We are grateful to Mike Peng (Editor-in-Chief) and the two anonymous reviewers for their helpful comments on earlier versions of this paper. We also acknowledge the financial grant from the National Science Council, Taiwan (NSC 94-2416-H-002-059). Earlier versions of this work were presented at the 2006 Asia Academy of Management Conference in Tokyo.

C.-M. Chuang

National Taiwan University, 1, Sec. 4, Roosevelt Road, Taipei 106, Taiwan

e-mail: cmchuang@management.ntu.edu.tw

C.-P. Lin $(\bowtie)$

Department of Business Administration, Aletheia University,

32, Chin Li Street, Tamshui, Taipei 251, Taiwan

e-mail: au4325@email.au.edu.tw 
on internal capital markets connected by family ties may provide a more efficient alternative to overcome the inefficiency of capital markets in emerging economies (Khanna \& Palepu, 1997, 2000; Luo \& Chung, 2005; Peng, Lee, \& Wang, 2005).

In addition, financial economists provide a similar prescription to this particular problem in emerging economies. They argue that in capital markets penalized by the problems of information asymmetry, establishing a financial holding company (FHC), which integrates operations in several financial markets under common governance and transfers customer-specific information among the FHC's divisions, can overcome the information asymmetry problems in financial markets and thus create synergies through cross-selling (Berger, 2003; Kanatas \& Qi, 2003; Kroszner, 1996; Kroszner \& Rajan, 1994, 1997; Rajan, 1996; Walter, 1997; Yasuda, 2005).

This article examines why and how an FHC can effectively realize the opportunities of cross-selling in an emerging economy and discusses the role social capital plays in this process. Social capital is the goodwill available to individuals or groups from their network of relationships (Adler \& Kwon, 2002). It is argued that social capital facilitates information sharing, mutual trust, and joint problem-solving, and thus enhances efficiency of transaction (McEvily \& Marcus, 2005; Peng \& Heath, 1996; Uzzi, 1996, 1997, 1999). But exactly how social capital facilitates cross-selling within an FHC is not known, especially in an emerging economy. In this context, the goal of this paper is to answer the following research questions: (1) What is the process and necessary conditions for effective cross-selling within an FHC? (2) What role does social capital play in this process? (3) What is the main route of effective cross-selling among various divisions in an FHC?

This paper attempts to contribute to two streams of literature. First, we contribute to the literature on emerging economies. Past studies reveal that institutional relatedness, defined as the degree of the informal embeddedness or interconnectedness with dominant institution, helps firms capitalize on economies of scope based on social capital in emerging economies (Peng \& Heath, 1996; Peng et al., 2005). This article provides empirical evidence demonstrating how FHCs can fully utilize their social capital to remedy the information asymmetry problems and realize economies of scope through cross-selling in an emerging economy.

Second, despite some evidence of cross-selling within the FHC (Jensen, 2003; Yasuda, 2005), the process and rationale of cross-selling still remain largely unclear. This paper studies this issue by examining the necessary conditions for effective cross-selling within an FHC. Furthermore, the route or direction of cross-selling is not systematically studied in literature. While both Jensen (2003) and Yasuda (2005) focus mainly on cross-selling from the commercial banking division to the investment banking division, Kanatas and Qi (2003) argue that cross-selling can also be accomplished from the underwriting division to the commercial banking division. Based upon the discussion of necessary conditions for effective crossselling, this article also investigates the major route of cross-selling within an FHC, both conceptually and empirically. 


\section{Theory and hypotheses}

\section{Financial holding companies}

An FHC is a holding company that concurrently operates in various financial service markets such as commercial banking, ${ }^{1}$ investment banking, ${ }^{2}$ asset management, ${ }^{3}$ and insurance (Saunders \& Walter, 1994; Walter, 1997). This broad range of universal banking ${ }^{4}$ services can thus be provided by different divisions under the common governance structure of a single $\mathrm{FHC}^{5}$.

Although economies of scope are expected to be created when these financial services are integrated under the common governance of $\mathrm{FHC}$, the process and rationale of this cross-selling remain controversial in literature. For example, Rajan (1996) argues that since credit evaluation is an important step in any funding process, it should cost less to a bank for such an analysis for the purposes of underwriting a new issue if the bank had a previous lending relationship with the same customer. However, no empirical evidence supports Rajan's argument. On the other hand, by using recent U.S. data, Jensen (2003) finds that a firm is more likely to use a certain bank as an underwriter if a commercial banking tie already exists between them. Jensen's argument differs from Rajan's in that while Jensen focuses on the transferable customer relationship as the major determinant and rationale for the cross-selling, Rajan emphasizes the role of tacit knowledge of customer's credit.

Yasuda (2005) also provides evidence that bank relationships have positive impacts on a customer's underwriter choice, using U.S. data similar to Jensen's work. Similar to Rajan's argument, Yasuda's work emphasizes the information advantage the bank already has with the customer, and argues that the information

\footnotetext{
${ }^{1}$ The core business of commercial banking is taking deposit and lending, and the spread between loan interest rate and deposit interest rate is the main source of their profits, with the (interest rate) spread risk and credit risk as the main sources of risks (Fabozzi \& Modigliani, 2003).

${ }^{2}$ The core business of investment banking is, among others, underwriting. Underwriting or public offering is the process that firms or governments issue securities (stocks and bonds) to finance their capital. Underwriters usually advertise the securities, buy the securities from the issuer, and distribute them to the public (Fabozzi \& Modigliani, 2003; Pollock, Porac, \& Wade, 2004). The bid-ask spread is the main sources of profits and risks faced by underwriters.

${ }^{3}$ Assets management is the business that issuing and managing mutual funds to invest in security market. Investment companies sell shares of mutual funds to the public and invest the proceeds in a diversified portfolio of securities. In Taiwan, the total size of mutual funds is over 60 billion U.S. dollars in 2006.

${ }^{4}$ Universal banking had long been prohibited in the U.S. and Japan. In the U.S., the Glass-Steagall Act of 1933 banned commercial banks from underwriting corporate securities for the conviction that universal banking operations were potentially connected to the Great Depression of 1929 (Benston, 1996). Similar provision was also appeared in Japan in the Security and Exchange Act since 1948 (Hoshi, 1996). After debate for decades, however, the Glass-Steagall Act was eventually terminated in 1999, when the Financial Service Modernization (Gramm-Leach-Bliley) Act was signed into law in the U.S. The FHC Act in Taiwan followed in 2001. The FHC Act was also enacted in Japan in 1997.

${ }^{5}$ Kroszner and Rajan (1997) argues that the holding company structure is a better governance form due to the built-in firewalls between divisions against the possible conflicts of interest.
} 
advantage can reduce the costs incurred when the bank provides underwriting service to the customer that has had a long-standing lending relationship with the bank. Kanatas and Qi (2003) also maintain that the underwriter of a commercial bank has the information advantage in regard to their customers over an independent underwriter. They further argue that the customer information collected from the underwriting process can be leveraged to the commercial banking segment without providing further empirical evidence.

The process and rationale of cross-selling within an FHC can also be investigated by means of the literature on emerging economies and, especially, on business groups in Asia. In Taiwan, even before the enactment of the FHC Act of 2001, family-owned financial groups such as China Trust Group, Cathay Group, Shin Kong Group, and Fubon Group had already established and engaged in various financial service markets. These financial groups are, in turn, part of a bigger familyowned conglomerate, whose diversification is partly based on institutional relatedness, such as exploiting social ties with the government and introducing internal capital market into an emerging economy (Chung, 2006; Peng et al., 2005; Peng \& Delios, 2006; Peng \& Luo, 2000).

Although financial groups linked by family ties can overcome some sorts of market imperfections as argued in the literature (Khanna \& Palepu, 2000, 1997; Luo \& Chung, 2005; Peng et al., 2005), exchange of customer information among financial institutions was completely prohibited before the enactment of the FHC Act in 2001. Therefore, the problems of information asymmetry in capital market still remain unsolved. It is because of the enactment of the FHC Act, in particular Articles 43 and 48, that FHCs are permitted to share their salespeople and customer information - i.e. social capital associated with customers - among divisions in Taiwan legitimately, and therefore realizing more benefits arising from institutional relatedness (Peng \& Delios, 2006; Peng et al., 2005). ${ }^{6}$

\section{Capital market imperfections in an emerging economy}

One of the major problems in emerging economies is that the development of market institutions, such as the legal infrastructure that provides the basis for effective corporate governance, has been slow and unsatisfactory (Hoskisson, Eden, Lau, \& Wright, 2000; Peng, 2003; Peng \& Zhou, 2005). Due to poor market infrastructure, the capital markets are less transparent and generate less information than is needed for investors to make effective decisions (Le, Venkatesh, \& Nguyen, 2006). Therefore, when the external capital market is used for capital allocation, it is generally very costly and ineffective (Khanna \& Palepu, 1997, 1999; Peng et al., 2005).

\footnotetext{
${ }^{6}$ One of the major purposes for the Taiwanese government to draw up the FHC Act, like that of many other financial deregulations in Taiwan (Chung, 2006), was to enhance competitive advantages of financial industries in Taiwan. It is expected that the competitive advantages come from the synergies arising from integrating financial institutions within an $\mathrm{FHC}$ that overcomes the information asymmetry problems in financial markets (Article 1 of the FHC Act, 2001; Rajan, 1996), although the empirical evidence is still not clear.
} 
Under these circumstances, it is suggested in the literature that establishing a large and diversified conglomerate and using the internal capital market to substitute for the external capital market may save costs and enhance the efficiency of resource allocation (Teece, 1982; Williamson, 1975), though the large conglomerate creates its own bureaucratic costs as well (Williamson, 1985). Recently, scholars have found that introducing family and friendship ties into the internal capital market can further reduce the agency costs within the conglomerate (Khanna \& Palepu, 2000, 1997; Luo \& Chung, 2005; Peng et al., 2005).

In Taiwan, the capital market is not as efficient as that in developed economies. The banks do not have enough information to judge which customers will repay a loan and which will not. In 2001, when the FHC Act was enacted, the overall nonperforming loan ratio of financial institutions was $8.16 \%$, compared to $2.82 \%$ in the U.S. In 2004, although the Taiwanese ratio declined to $3.28 \%$, it was still much higher than the U.S. average of $1.69 \%$. The major reason is the underdevelopment of market infrastructures, as described by Luo and Chung (2005: 408-409).

[In Taiwan, c]ompared with the speedy changes in deregulation, the establishment of market infrastructures was fragmented and slow...[T]here was still substantial information asymmetry in late 1990s. For example, the requirement for group firms to file consolidated reports was not implemented until 2001. Further, there were no independent bodies to ratify the financial information submitted. The first independent credit rating agency in Taiwan, Taiwan Rating, was launched only in 1997. Until 2004, only 72 financial institutions and 28 companies were rated and had their reports available online. There is also a shortage of professional analysts. According to Nelson's Directory of Investment Research, there were only 138 equity analysts in Taiwan in 1998. When Moody's and Fitch Ratings joined the credit-assessment market in Taiwan in 2002, they could not find qualified analysts and had to draw on their analysts in Hong Kong and Singapore to support their business.

For similar reasons, firms in Taiwan are usually unwilling to raise funds from the stock market or banking system (Hamilton, 1997). It is estimated that $45-55 \%$ of the capital of manufacturing firms come from accumulated profits and 30\% from informal sources such as family, friends, and mutual aid associations (Hamilton, 1997). Without a social relationship, the borrower seems untrustworthy to the bank. Thus a long credit investigation process or full collateral is inevitable, which in turn undermines the firm's capability for adjustment to market changes and increases the costs of capital.

\footnotetext{
${ }^{7}$ How effective this "internal capital market" will replace external capital market depends at least partly on the development of the economy. Khanna and Palepu (2000) find that firms associated with a business group led to a significantly better performance at earlier stages of economy development than at the later stages. Peng et al. (2005) also maintain that the optimal scope of the firm is likely to contract in the long run. They argue that the capital markets are more inefficient at earlier stages and internalizing capital market within conglomerates can save costs. Accompanied with the development of economy, the external capital market conditions improved, and the advantages of employing internal capital markets may disappear gradually.
} 
Social capital to mitigate market imperfections

We maintain that social capital arising from the embedded ties between financial institutions and their customers, accompanied with the intra-firm transfer of customer-specific knowledge and information within an FHC, generates crossselling opportunities among various divisions, providing an effective way to create synergies and overcome financial market imperfections in an emerging economy.

Three mechanisms through which social capital and embedded ties are able to overcome financial market imperfections are identified in the relative literature: trust, fine-grained information transfer, and joint problem-solving (Uzzi, 1996, 1997). Financial transactions are usually hazardous due to information asymmetry. For example, a commercial bank needs information upon which to predict which customers will repay loans and which will not. However, the information is not fully available in financial markets. Through embedded ties, a commercial bank can access and accumulate the customer-specific information from past transaction experiences (Uzzi, 1999; Yasuda, 2005), through continuous monitoring process (Agarwal \& Elston, 2001; Gorton \& Schmid, 2000; Macey, 2000) or through friendship and family relationships (Hamilton, 1997; Peng \& Luo, 2000; Yeung, 2006). In this manner, the commercial bank is able to pay less costs to investigate the credit of a customer and can therefore provide cheaper loan service.

When a bank believes that a customer will repay a loan and decides to loan to the customer, it is said that the bank trusts the customer. Trust is referred to as the decision to rely on another under the condition of risk (Curral \& Inkpen, 2002). The continual interactions through embedded ties convey information that mitigates the problems of information asymmetry and breeds trust (Nahapiet \& Ghoshal, 1998; Zucker, 1986). When a bank trusts a customer and perceives less transaction hazards, the risk premium charged by the bank then declines, and the willingness of the customer to transact with the bank increases accordingly.

In addition to transaction hazards, some other costs may also incur when using an arm's-length market in search of financial services. Lack of knowledge about a customer's financial problems, strategies, and preferences makes the solutions proposed by a bank less appropriate to the customer. On the other hand, embedded ties provide a bank with a longer time horizon to acquire knowledge about the customer (Kotabe, Martin, \& Domoto, 2003; Uzzi, 1996, 1997, 1999). The trust and information sharing through embedded ties also breeds customer willingness to work cooperatively (McEvily \& Marcus, 2005), and the solutions proposed by the bank are thus more customer-made and effective.

As argued by Adler and Kwon (2002), both market relations (such as past transactions) and social relations (such as friendship and family ties) are appropriable and will be the key sources of social capital. The appropriability of the relation is referred to as the relation, and once brought into existence for one set of purposes, can also aid others (Coleman, 1988). Earlier research demonstrates that friendship and family ties are effective control mechanisms in hazardous transactions and thus facilitate the establishment of market relations and transactions (Peng \& Luo, 2000; Pfeffer \& Salancik, 1978). When no social relationship exists between the lender and the borrower, the process of credit investigation, in the absence of effective market infrastructure (such as credit checks), will be lengthy and costly (Hamilton, 1997). 
Figure 1 Factors affecting cross-selling within an $\mathrm{FHC}$

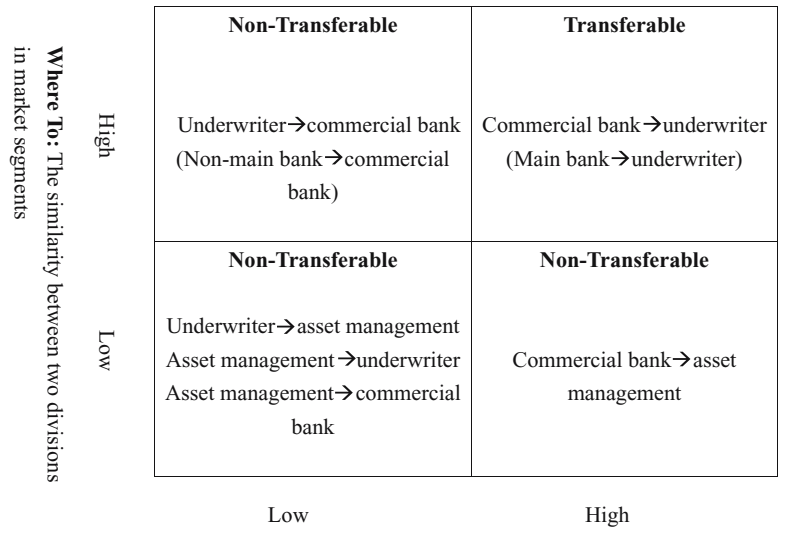

Where From: The degree to which the FHC has knowledge about the customer

Therefore, if embedded ties and social capital exist between a financial institution and a customer, the frequency of transactions will increase. ${ }^{8}$ More formally:

Hypothesis 1 A customer's likelihood of choosing a division in an FHC for providing financial services increases with the degree of embeddedness between the division and the customer.

We want to explore the impact of social capital on the search for a transaction party for different types of financial services. Therefore,

Hypothesis 1a A customer's likelihood of choosing a commercial bank in an FHC for providing commercial loan increases with the degree of embeddedness between the commercial bank and the customer.

Hypothesis 1b A customer's likelihood of choosing an underwriter in an FHC for providing underwriting services increases with the degree of embeddedness between the underwriter and the customer.

Hypothesis 1c A customer's likelihood of choosing an asset management division in an FHC for providing asset management service increases with the degree of embeddedness between the asset management division and the customer.

Necessary conditions for effective cross-selling in FHCs: "where from" and "where to" conditions

We argue that, as shown in Figure 1, for cross-selling within an FHC to be effective, the following two conditions must be satisfied: (1) "where from" condition-an FHC has to have embedded ties with the customers in order to have sufficient and comprehensive customer knowledge, and (2) "where to" condition-the target markets of the two divisions must overlap at least partially so that the customerspecific knowledge can be leveraged and exploited to other business opportunities.

\footnotetext{
${ }^{8}$ Past studies suggest that frequency of transactions is an adequate measurement for embeddedness (Chung, Singh, \& Lee, 2000; Curral \& Inkpen, 2002; Gulati, 1995; Gulati \& Gargiulo, 1999; Pollock et al., 2004).
} 
"Where from" condition

Cross-selling opportunities within an FHC originate from its possession of a critical but scarce resource, i.e., the comprehensive and tacit customer-specific information and knowledge, which is obtained and accumulated through the embedded ties between the customer and the divisions of an FHC. Nevertheless, the customerspecific knowledge accumulated from various divisions differs with respect to its quality and amount. Therefore, its potential value for creating cross-selling within an FHC is diverse. In this regard, we maintain that cross-selling within an FHC is mainly initiated from the commercial banking division.

In general, commercial banks hold the strongest ties with their customers and will ceaselessly monitor their customers until the loans are repaid. Unlike individual investors and underwriters in securities markets, commercial banks have the ability and strong willingness to monitor the borrower. Their capital at stake is large, and they keep the loan on their balance sheet as an asset, thus internalizing all the costs and benefits associated with the loan (Macey, 2000). Through the process of continual monitoring and social interactions, commercial banks have accumulated the wideranging knowledge of customers, including customers' credit, unique financial problems, strategies, and prospects. Compared to other divisions, commercial banks have the most comprehensive knowledge about their customers which is applicable and hence valuable to other divisions within an FHC, such as underwriting.

From the customers' point of view, the continual social interactions breed trust in the commercial banking division, causing them to transfer private information to the banks, and establish the routines for joint problem-solving (Uzzi, 1999). These social mechanisms will also be extended to the underwriting division and will be instrumental in curbing the transaction hazards and enhancing transaction efficiency.

On the other hand, the knowledge obtained from the underwriting division is not as comprehensive and valuable as the one obtained from the commercial banking division. Underwriters usually do not have customer relationships strong enough to gain sufficient and wide-ranging knowledge of their customers. In particular, underwriters usually do not monitor customers continually, because the securities they buy from the customer will be re-sold in the very short run (Macey, 2000). Therefore, the knowledge accumulated from the underwriting division may not be sufficient and/or rich enough to create value and business opportunities for other divisions.

\section{"Where to" condition}

After gaining customer knowledge, the commercial bank in the FHC has to transfer the knowledge to other divisions within the FHC to realize the opportunity of crossselling. Though transferring knowledge within a firm is easier than across firms (Kogut and Zander, 1993), it is by no means easy. Among other factors, the "similarity between divisions" factor is identified as a major determinant affecting the effectiveness of intra-firm knowledge transfer in literature (Cohen \& Levinthal, 1990; Grant, 1996; Nonaka \& Takeuchi, 1994; Tanriverdi \& Venkatraman, 2005; Tsai, 2001). In this research, similarity between the divisions' market segments is particularly important. For example, commercial banking and assets management target different market segments. While commercial banking targets those who need 
funds to provide loan service, assets management eyes those who have slack funds. The customer knowledge in one business is not applicable to the other and therefore the cross-selling between the two divisions is unlikely to happen.

Among other divisions, commercial banks and underwriters target similar market segments, whereas their customers are those who need funds. When the commercial banking division transfers customer-specific knowledge to the underwriting division, the latter is able to provide underwriting service to these customers at a better quality and a lower cost, thus enhancing transaction efficiency (Rajan, 1996; Yasuda, 2005).

The major route of cross-selling within an FHC

Based upon the examination of both "where from" and "where to" conditions discussed above, this article maintains that the major route of effective cross-selling within an FHC is from the commercial banking division to the underwriting division.

There is no cross-selling from the underwriting to commercial banking because the "where from" condition is not met. Similarly, like there is no cross-selling between underwriting and assets management, nor is there cross-selling between commercial banking and assets management because the "where to" condition is not satisfied. Therefore,

Hypothesis 2 The cross-selling from commercial banking to underwriting within an FHC is more effective than other routes.

Since a customer may transact with different commercial banks simultaneously, a main commercial bank usually maintains stronger ties with its customer than nonmain commercial banks do. Therefore, we argue further that the customer's main commercial banks will more effectively transfer their customers to the underwriting division than non-main commercial banks will. ${ }^{9}$ Yasuda (2005) reaches a similar conclusion saying that the commercial bank which serves as an arranger of past loans can transfer the customer to the underwriting division, whereas a bank serving merely as a participant can not. Therefore,

Hypothesis 3 Customer's main banks will transfer their customer to the underwriting division within an FHC more effectively than non-main banks.

\section{Methods}

\section{Data sets}

Since the enactment of the FHC Act of 2001 in Taiwan, 14 FHCs have been established. All of them have been included in this empirical test. The unit of

\footnotetext{
${ }^{9}$ A main bank is a commercial bank which maintains strong tie with a certain customer. A main bank is defined as a commercial bank which loans to a certain customer and the amount of the loans is above $30 \%$ of the total loans the customer borrowed. Sensitivity analysis was performed when using various cutoff ratios as 20,30 , or $40 \%$, the results are all similar. By this operating definition, a customer may have two main banks or more.
} 
analysis is the dyad relationship between the divisions of FHCs and their customers. The divisions include commercial banks, underwriters, and assets management. The customers include 1,087 non-financial firms listed in the Taiwan Stock Exchange or the OTC market. During the period 1998-2004, there were 34,795 commercial loan transactions, 692 underwriting transactions, and 4,226 mutual fund transactions. These transactions are all included in this research. The underwriting transactions include initial public offerings, stock offerings, and convertible bond offerings. Only lead and co-lead managers underwriting dyads are included in our sample, because participants in the underwriting syndicate are often chosen by the lead underwriter, rather than by the customer (issuer), and their compensations are far below that of the lead underwriter (Chung et al., 2000). Participants seldom have contact with the issuer.

When a financial institution was merged or acquired by an FHC, its transactions and ties were incorporated in the corresponding division of the FHC. For example, Chiao Tung Bank and International Commercial Bank of China were merged into Mega Bank, and Taipei Bank and Fubon Bank were merged into Taipei Fubon Bank. Our data source is mainly from Taiwan Economic Journal, and the missing data is amended from Market Observation Post System of the Taiwan Stock Exchange.

Among the 14 FHCs, 13 owned underwriting divisions. Thus, the maximal potential underwriting dyads were 14,131 pairs $(1,087 \times 13-1,087$ is the number of potential customers). Among the 14,131 underwriting dyads, only 131 dyads were realized in 2003 and 2004. The number of FHCs that owned commercial banks were 12. Thus, the maximal potential commercial loan dyads were 13,044 pairs $(1,087 \times$ 12). Among the 13,044 commercial loan dyads, 2,195 dyads were realized in 2003 and 2004. There were six FHCs that owned assets management division; thus, the maximal potential dyads of buying mutual funds were 6,522 pairs $(1,087 \times 6)$. Among these dyads, 363 dyads were realized in 2003 and 2004. The distribution of these realized ties across FHCs is shown in Table 1. In 2003, when the dependent variables started to be counted, all 14 FHCs were established and included in our data set. ${ }^{10}$

\section{Statistical model}

The following logistic regression is used to test the factors affecting the likelihood of a customer choosing a division of an FHC as a provider of financial services.

$$
P(y=1 \mid x)=\frac{1}{1+e^{-x \beta}}
$$

If new ties are present, $y=1$ is coded; otherwise, 0 is coded. $x$ denotes a vector of explanatory variables, and $\beta$ denotes the vector of coefficients.

\footnotetext{
${ }^{10}$ Indeed, our data are not time-series cross-section (panel) but just cross-sectional. Although we collected the transaction data from 1998 to 2004, the data from 1998 to 2002 were only considered as explanatory variables and not included in dependent variables for two reasons. First, not all FHCs were established during this period. The last FHC (First) was established on January 2, 2003 (see Table 1). Second, we need the frequency of the transactions during past 5 years as explanatory variables. Therefore, only the transactions after the fifth year (2003 and 2004) can be counted as dependent variables (Jensen, 2003; Gulati, 1995). The transactions in 2003 and 2004 were combined to avoid the problem that realized underwriting dyads in each year were too few. Thus, our data are only cross-sectional.
} 
Table 1 The distribution of realized ties across FHCs.

\begin{tabular}{|c|c|c|c|c|c|}
\hline FHC names & $\begin{array}{l}\text { Established } \\
\text { date }\end{array}$ & $\begin{array}{l}\text { Total assets } \\
\text { (billion U.S. } \\
\text { dollars) } \\
\text { 9/30/2004 }\end{array}$ & $\begin{array}{l}\text { Underwriting } \\
\text { division [\# of ties } \\
(2003-2004)]\end{array}$ & $\begin{array}{l}\text { Commercial } \\
\text { banks [\# of ties } \\
(2003-2004)]\end{array}$ & $\begin{array}{l}\text { Asset managemen } \\
\text { division [\# of ties } \\
(2003-2004)]\end{array}$ \\
\hline \multirow[t]{2}{*}{ Cathay } & \multirow[t]{2}{*}{$12 / 31 / 2001$} & \multirow[t]{2}{*}{75.83} & - & $\begin{array}{l}\text { Cathay United } \\
\text { Bank }\end{array}$ & - \\
\hline & & & - & 106 & - \\
\hline \multirow[t]{2}{*}{ Mega } & \multirow[t]{2}{*}{$2 / 4 / 2002$} & \multirow[t]{2}{*}{59.58} & Mega Securities & $\begin{array}{l}\text { Mega } \\
\text { International } \\
\text { Commercial } \\
\text { Bank }\end{array}$ & Mega funds \\
\hline & & & 16 & 407 & 66 \\
\hline \multirow[t]{2}{*}{ Hua Nan } & \multirow[t]{2}{*}{$12 / 19 / 2001$} & \multirow[t]{2}{*}{46.98} & $\begin{array}{l}\text { Hua Nan } \\
\text { Securities }\end{array}$ & Hua Nan Bank & $\begin{array}{l}\text { Hua Nan } \\
\text { Investment Trust }\end{array}$ \\
\hline & & & 13 & 314 & 76 \\
\hline \multirow[t]{2}{*}{ First } & \multirow[t]{2}{*}{$1 / 2 / 2003$} & \multirow[t]{2}{*}{45.72} & $\begin{array}{c}\text { First Taisec } \\
\text { Securities }\end{array}$ & First Bank & $\begin{array}{l}\text { National } \\
\text { Investment Trust }\end{array}$ \\
\hline & & & 5 & 268 & 76 \\
\hline \multirow[t]{2}{*}{ Fubon } & \multirow[t]{2}{*}{$12 / 19 / 2001$} & \multirow[t]{2}{*}{45.47} & Fubon Securities & $\begin{array}{l}\text { Taipei Fubon } \\
\text { Bank }\end{array}$ & $\begin{array}{l}\text { Fubon Asset } \\
\text { Management }\end{array}$ \\
\hline & & & 6 & 143 & 55 \\
\hline \multirow[t]{2}{*}{ Chinatrust } & \multirow[t]{2}{*}{$5 / 17 / 2002$} & \multirow[t]{2}{*}{42.48} & $\begin{array}{l}\text { Chinatrust } \\
\text { Securities }\end{array}$ & $\begin{array}{l}\text { Chinatrust } \\
\text { Commercial } \\
\text { Bank }\end{array}$ & - \\
\hline & & & 10 & 216 & - \\
\hline \multirow[t]{2}{*}{ Shin Kong } & \multirow[t]{2}{*}{$2 / 19 / 2002$} & \multirow[t]{2}{*}{26.94} & $\begin{array}{r}\text { Shin Kong } \\
\text { Securities }\end{array}$ & - & - \\
\hline & & & 1 & - & - \\
\hline \multirow[t]{2}{*}{ Taishin } & \multirow[t]{2}{*}{$2 / 18 / 2002$} & \multirow[t]{2}{*}{23.94} & Taiwan Securities & $\begin{array}{l}\text { Taishin } \\
\text { International } \\
\text { Bank }\end{array}$ & - \\
\hline & & & 14 & 226 & - \\
\hline \multirow[t]{2}{*}{ SinoPac } & \multirow[t]{2}{*}{$5 / 9 / 2002$} & \multirow[t]{2}{*}{17.25} & $\begin{array}{l}\text { SinoPac } \\
\text { Securities }\end{array}$ & Bank SinoPac & - \\
\hline & & & 24 & 78 & - \\
\hline E.Sun & $1 / 28 / 2002$ & 14.62 & $\begin{array}{l}\text { E.Sun Securities } \\
0\end{array}$ & $\begin{array}{l}\text { E.Sun Bank } \\
105\end{array}$ & $\begin{array}{l}\text { E.Sun SITC } \\
18\end{array}$ \\
\hline \multirow[t]{2}{*}{ Fuhwa } & \multirow[t]{2}{*}{$2 / 4 / 2002$} & 10.23 & Fuhwa Securities & Fuhwa Bank & $\begin{array}{l}\text { Fuhwa Securities } \\
\text { Investment Trust }\end{array}$ \\
\hline & & & 5 & 109 & 72 \\
\hline Jih Sun & $2 / 5 / 2002$ & 9.03 & $\begin{array}{l}\text { Jih Sun } \\
\text { Securities }\end{array}$ & Jih Sun Bank & - \\
\hline & & & 8 & 142 & - \\
\hline $\begin{array}{l}\text { China } \\
\text { Development }\end{array}$ & $12 / 28 / 2001$ & 7.63 & $\begin{array}{l}\text { Grand Cathay } \\
\text { Securities }\end{array}$ & $\begin{array}{l}\text { China } \\
\text { Development } \\
\text { Industrial } \\
\text { Bank }\end{array}$ & - \\
\hline & & & 26 & 81 & - \\
\hline Waterland & $3 / 26 / 2002$ & 5.99 & $\begin{array}{l}\text { Waterland } \\
\text { Securities }\end{array}$ & - & - \\
\hline & & & 3 & - & - \\
\hline Total & & 431.69 & 131 & 2,195 & 363 \\
\hline
\end{tabular}

A dash means that the FHC did not own this division before 2003. 
Our unit of analysis is the dyads between FHCs and their customers, which means an FHC may appear in more than one dyad; therefore, these dyads are not independent. For example, if First Bank has more ties than average, the probabilities of $y=1$ in two dyads associated with First Bank will both be high; hence, the two dyads are not independent of each other. This problem is parallel with the panel or time-series cross-section data in that the data in the same time period does not independent on each other (Lincoln, 1984). To overcome the problem of the dyads associated with the same FHC not being independent, we impose a dummy variable on each FHC, which is the fixed effects approach for panel data (Greene, 2000). The fixed effects model can capture and control the differences of constant terms between FHCs in the regression functions. ${ }^{11}$

\section{Dependent variables}

Our dependent variables are whether or not a customer chooses a division of an FHC as a provider of financial services. If the new transactions presented between them is during 2003-2004, then $y=1$ is coded; otherwise 0 is coded (Chung et al., 2000; Gulati, 1995; Gulati \& Gargiulo, 1999; Jensen, 2003; Yasuda, 2005). Since three kinds of FHC divisions are studied in this research (commercial banks, underwriters, and asset management divisions), there are three dependent variables and three logistic regression models needed to explain each separately.

\section{Explanatory variables}

Embedded ties Embedded ties are measured by the number of past transaction ties (Chung et al., 2000; Curral and Inkpen, 2002; Gulati, 1995; Gulati \& Gargiulo, 1999; Pollock et al., 2004) between a customer and a division of an FHC during 1998-2002. The higher the frequency of past transactions is, the higher the degree of embeddedness.

Other divisions' ties To measure the transferability of customer relationships to another division, we need the data of other divisions' ties to the same customer. This construct is measured by the number of past transaction ties between the customer and other divisions within the same FHC during 1998-2002 (Chung et al., 2000; Gulati, 1995; Gulati \& Gargiulo, 1999).

Main bank relationships A main bank of a customer is a commercial bank which has strong ties with that customer. Here we code main bank relationship as 1 if a

\footnotetext{
${ }^{11}$ Heteroscedasticity is quite a common problem in panel data. The variance of a normally distributed dependent variable may vary with groups. In the logistic regression model, where the dependent variable is Bernoulli distributed, the variance is determined only by the probability, which can be estimated by maximum-likelihood method. When y is binary and complies with Bernoulli distribution, the variance of $\mathrm{y}$ is $\sigma^{2}=V(y)=P(1-P)$ and determined only by $\mathrm{P}$. $\mathrm{P}$ is the probability that $\mathrm{y}=1$ and $P=1 /\left(1+e^{-x \beta}\right)$ in logistic model. As the $\mathbf{x}$ varies, $\mathrm{P}$ and thus $\sigma^{2}$ vary as well. That seems to be the problem of heteroscedasticity. Because the structure of variance is clear, using the maximum-likelihood method to estimate $\beta$ and thus $\mathrm{P}$ and $\sigma^{2}$ simultaneously can solve this problem. Therefore, we employ the maximumlikelihood method to estimate $\beta$.
} 
commercial bank loans to a customer and the amount of the loans were above $30 \%$ of the total loans the customer borrowed during 1998-2002; otherwise 0 is coded.

Non-main bank relationships A non-main bank relationship exists when a commercial bank maintains weak ties to a customer. In this research we code nonmain bank relationships as 1 if a commercial bank loans to a customer and the amount of the loans were below $30 \%$ of the total loans the customer borrowed during 1998-2002; otherwise 0 is coded.

\section{Control variables}

Several control variables are employed in this test. First, we control the experience of a customer in a certain financial market, measured as the number of financial institutions with which a customer has experience to transact in the market. Second, we control the size of a customer, which is equal to the natural log of the total assets of the customer. Third, the company age of a customer is controlled. Fourth, we control the squared terms of embedded ties and other divisions' ties as Uzzi (1996, 1997, 1999) and Gulati (1995) argue that too much embeddedness may be harmful. Because underwriting ties squared are highly collinear with the underwriting ties, this squared term is omitted. Finally, we assign a dummy variable to each FHC to control the fixed effects resulting from panel data, as described above. When introducing dummy variables to FHCs, employing the control variables of characteristics of FHCs (e.g., FHC size) is not feasible due to multicollinearity.

\section{Results}

Table 2 summarizes the descriptive statistics. Tables 3, 4 and 5 report the findings for underwriters, commercial banks, and assets management divisions of FHCs, respectively. In general, the results provide broad support for our hypotheses. In all three tables, Model 1 is the baseline model that contains only control variables, and the main explanatory variables are added in Models 2 and 3.

First, Tables 3, 4, and 5 show that the effects of embedded ties are significant no matter in underwriting market, commercial banking market, or asset management market, supporting Hypothesis 1 .

Second, regarding the determinants of customers' choice of underwriters, Table 3 reveals that it is the commercial banking ties, not the asset management ties, that matter. In addition, neither the underwriting ties nor the asset management ties are important to the customers' choice of commercial banking (Table 4). Similarly, neither the underwriting ties nor the commercial banking ties in regard to customers' choices of asset management service are significant (Table 5). All these results support Hypothesis 2 that cross-selling is effective only from the commercial banking market to the underwriting market within an FHC, not the other way around.

Finally, Model 3 of Table 3 shows that in regard to the effects of commercial bank ties on the customers' choice of underwriters, only the main commercial bank ties matter. Non-main commercial bank ties show no significant influence here, supporting Hypothesis 3. 


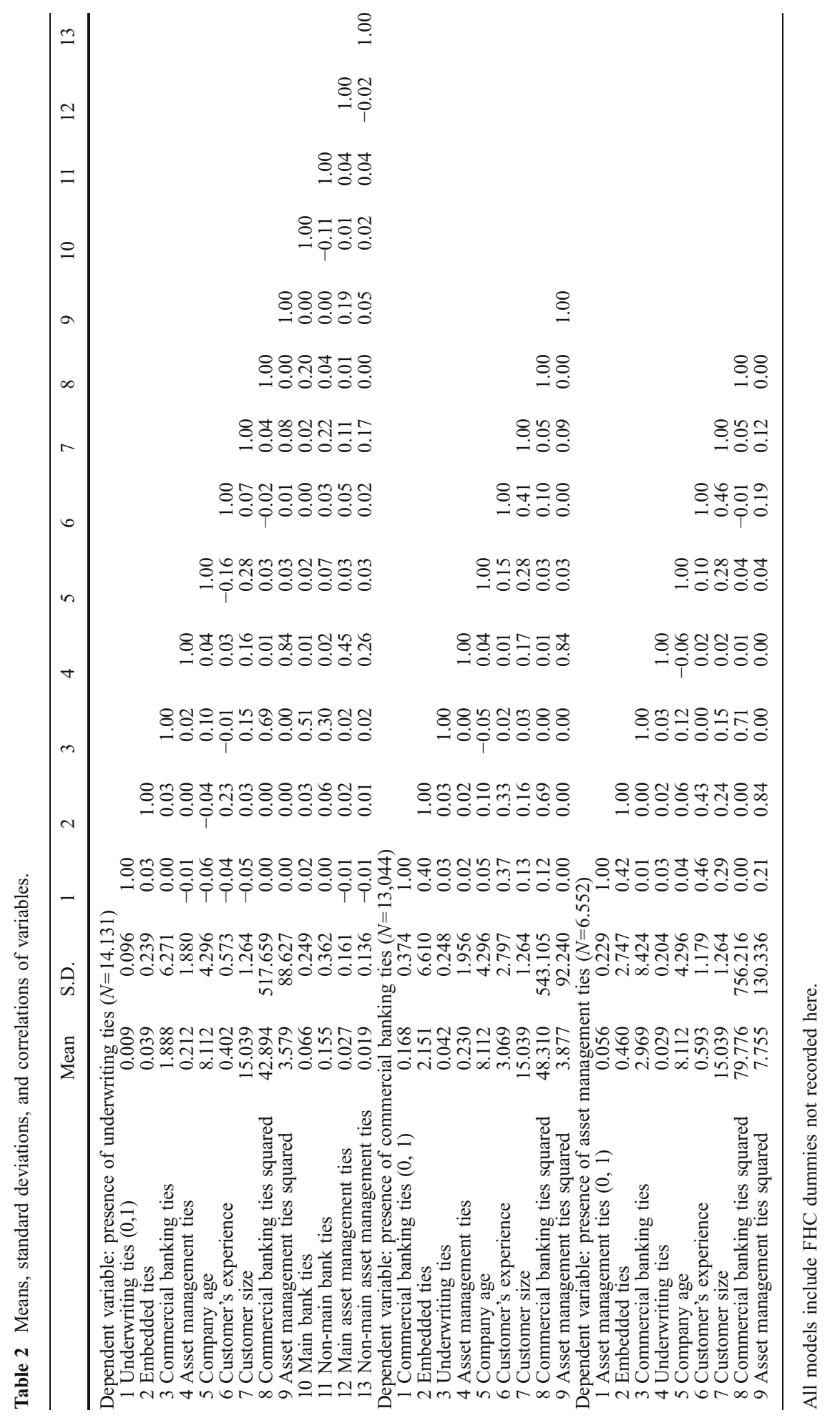


Table 3 Logistic regression: Underwritng subsidiaries of FHCs.

\begin{tabular}{|c|c|c|c|}
\hline & Model 1 & Model 2 & Model 3 \\
\hline Embedded ties & & $\begin{array}{l}1.059 * * * * \\
(0.236)\end{array}$ & $\begin{array}{l}1.086 * * * * \\
(0.237)\end{array}$ \\
\hline Commercial banking ties & & $\begin{array}{l}0.092 * * * \\
(0.038)\end{array}$ & \\
\hline Asset management ties & & $\begin{array}{l}1.081 \\
(1.176)\end{array}$ & \\
\hline Main bank ties & & & $\begin{array}{l}0.575 * * \\
(0.306)\end{array}$ \\
\hline Non-main bank ties & & & $\begin{array}{l}0.247 \\
(0.278)\end{array}$ \\
\hline Main asset management ties & & & $\begin{array}{l}-0.455 \\
(1.027)\end{array}$ \\
\hline Non-main asset management ties & & & $\begin{array}{l}0.139 \\
(1.030)\end{array}$ \\
\hline Commercial banking ties squared & & $\begin{array}{l}-0.002 \\
(0.001)\end{array}$ & \\
\hline Asset management ties squared & & $\begin{array}{l}-0.467 \\
(0.510)\end{array}$ & \\
\hline Customer's experience & $\begin{array}{l}-1.105^{* * * *} \\
(0.232)\end{array}$ & $\begin{array}{l}-1.475 * * * * \\
(0.277)\end{array}$ & $\begin{array}{l}-1.476 * * * * \\
(0.277)\end{array}$ \\
\hline Customer size & $\begin{array}{l}-0.293 * * * * \\
(0.087)\end{array}$ & $\begin{array}{l}-0.345 \\
(0.091)\end{array}$ & $\begin{array}{l}-0.330 * * * * \\
(0.091)\end{array}$ \\
\hline Company age & $\begin{array}{l}-0.193 * * * * \\
(0.029)\end{array}$ & $\begin{array}{l}-0.201 * * * * \\
(0.030)\end{array}$ & $\begin{array}{l}0.196 * * * * \\
(0.029)\end{array}$ \\
\hline Intercept & $\begin{array}{l}0.487 \\
(1.294)\end{array}$ & $\begin{array}{l}1.167 \\
(1.333)\end{array}$ & $\begin{array}{l}0.947 \\
(1.335)\end{array}$ \\
\hline Mega & $\begin{array}{l}1.185 * * \\
(0.516)\end{array}$ & $\begin{array}{l}1.049 * * \\
(0.521)\end{array}$ & $\begin{array}{l}1.053 * * \\
(0.520)\end{array}$ \\
\hline Hua Nan & $\begin{array}{l}0.971^{*} \\
(0.530)\end{array}$ & $\begin{array}{l}0.957^{*} \\
(0.532)\end{array}$ & $\begin{array}{l}0.945^{*} \\
(0.531)\end{array}$ \\
\hline Waterland & $\begin{array}{l}-0.515 \\
(0.733)\end{array}$ & $\begin{array}{l}-0.356 \\
(0.739)\end{array}$ & $\begin{array}{l}-0.386 \\
(0.740)\end{array}$ \\
\hline Jih Sun & $\begin{array}{l}0.476 \\
(0.574)\end{array}$ & $\begin{array}{l}0.565 \\
(0.579)\end{array}$ & $\begin{array}{l}0.537 \\
(0.579)\end{array}$ \\
\hline Fuhwa & $\begin{array}{l}0.000 \\
(0.636)\end{array}$ & $\begin{array}{l}0.136 \\
(0.639)\end{array}$ & $\begin{array}{l}0.113 \\
(0.640)\end{array}$ \\
\hline Fubon & $\begin{array}{l}0.184 \\
(0.609)\end{array}$ & $\begin{array}{l}0.200 \\
(0.611)\end{array}$ & $\begin{array}{l}0.200 \\
(0.611)\end{array}$ \\
\hline Shin Kong & $\begin{array}{l}-1.617 \\
(1.097)\end{array}$ & $\begin{array}{l}-1.456 \\
(1.101)\end{array}$ & $\begin{array}{l}-1.485 \\
(1.102)\end{array}$ \\
\hline E.Sun & $\begin{array}{l}-5.719 \\
(7.780)\end{array}$ & $\begin{array}{l}-9.573 \\
(56.592)\end{array}$ & $\begin{array}{l}-5.599 \\
(7.692)\end{array}$ \\
\hline Taishin & $\begin{array}{l}1.048 * * \\
(0.525)\end{array}$ & $\begin{array}{l}1.062 * * \\
(0.530)\end{array}$ & $\begin{array}{l}1.049 * * \\
(0.530)\end{array}$ \\
\hline China Development & $\begin{array}{l}1.691 * * * * \\
(0.492)\end{array}$ & $\begin{array}{l}1.689 * * * * \\
(0.499)\end{array}$ & $\begin{array}{l}1.674 * * * * \\
(0.499)\end{array}$ \\
\hline SinoPac & $\begin{array}{l}1.607 * * * \\
(0.496)\end{array}$ & $\begin{array}{l}1.702 * * * * \\
(0.504)\end{array}$ & $\begin{array}{l}1.664 * * * * \\
(0.504)\end{array}$ \\
\hline China Trust & $\begin{array}{l}0.703 \\
(0.551)\end{array}$ & $\begin{array}{l}0.737 \\
(0.556)\end{array}$ & $\begin{array}{l}0.722 \\
(0.556)\end{array}$ \\
\hline$-2 \mathrm{LR}$ & $1,279.917$ & $1,256.197$ & $1,261.379$ \\
\hline & 207.268 & 230.988 & 225.807 \\
\hline Degrees of freedom & 15 & 20 & 20 \\
\hline
\end{tabular}

Dependent variable: presence of underwriting ties $(N=14,131)$. One tailed tests for main variables; two tailed tests for control variables. Standard errors are in parentheses; the based model is First FHC.

$* p<0.1$

$* * p<0.05$

$* * * p<0.01$

$* * * * p<0.001$ 
Table 4 Logistic regression: Commercial banking subsidiaries of FHCs.

\begin{tabular}{|c|c|c|}
\hline & Model 1 & Model 2 \\
\hline Embedded ties & & $\begin{array}{l}0.177 * * * * \\
(0.008)\end{array}$ \\
\hline Underwriting ties & & $\begin{array}{l}0.092 \\
(0.105)\end{array}$ \\
\hline Asset management ties & & $\begin{array}{l}0.025 \\
(0.027)\end{array}$ \\
\hline Commercial banking ties squared & & $\begin{array}{l}-0.002 * * * * \\
(0.000)\end{array}$ \\
\hline Asset management ties squared & & $\begin{array}{l}0.000 \\
(0.001)\end{array}$ \\
\hline Customer's experience & $\begin{array}{l}0.382 * * * * \\
(0.011)\end{array}$ & $\begin{array}{l}0.288 * * * * \\
(0.012)\end{array}$ \\
\hline Customer size & $\begin{array}{l}-0.087 * * * * \\
(0.025)\end{array}$ & $\begin{array}{l}-0.103 * * * * \\
(0.027)\end{array}$ \\
\hline Company age & $\begin{array}{l}0.003 \\
(0.006)\end{array}$ & $\begin{array}{l}-0.017 * * \\
(0.007)\end{array}$ \\
\hline Intercept & $\begin{array}{l}-1.220 * * * * \\
(0.353)\end{array}$ & $\begin{array}{l}-1.026^{* * * *} \\
(0.381)\end{array}$ \\
\hline Mega & $\begin{array}{l}0.752 * * * * \\
(0.105)\end{array}$ & $\begin{array}{l}0.357 * * * \\
(0.118)\end{array}$ \\
\hline Hua Nan & $\begin{array}{l}0.268 * * \\
(0.108)\end{array}$ & $\begin{array}{l}0.232 * * \\
(0.117)\end{array}$ \\
\hline Jih Sun & $\begin{array}{l}-0.944 * * * * \\
(0.126)\end{array}$ & $\begin{array}{l}-5.554 * * * * \\
(0.133)\end{array}$ \\
\hline Fuhwa & $\begin{array}{l}-1.294 * * * * \\
(0.134)\end{array}$ & $\begin{array}{l}-0.798^{* * * * *} \\
(0.140)\end{array}$ \\
\hline Fubon & $\begin{array}{l}-0.935 * * * * \\
(0.125)\end{array}$ & $\begin{array}{l}-0.812^{* * * * *} \\
(0.134)\end{array}$ \\
\hline Cathay & $\begin{array}{l}-1.330 * * * * \\
(0.135)\end{array}$ & $\begin{array}{l}-1.022 * * * * \\
(0.143)\end{array}$ \\
\hline E.Sun & $\begin{array}{l}-1.342 * * * * \\
(0.136)\end{array}$ & $\begin{array}{l}-0.857 * * * * \\
(0.142)\end{array}$ \\
\hline Taishin & $\begin{array}{l}-0.272 * * \\
(0.114)\end{array}$ & $\begin{array}{l}-0.140 \\
(0.123)\end{array}$ \\
\hline China Development & $\begin{array}{l}-1.666^{* * * *} \\
(0.146)\end{array}$ & $\begin{array}{l}-1.453 * * * * \\
(0.156)\end{array}$ \\
\hline SinoPac & $\begin{array}{l}-1.712^{* * * *} \\
(0.148)\end{array}$ & $\begin{array}{l}-1.134 * * * * \\
(0.152)\end{array}$ \\
\hline China Trust & $\begin{array}{l}-0.341 * * * \\
(0.115)\end{array}$ & $\begin{array}{l}-0.200 \\
(0.123)\end{array}$ \\
\hline$-2 \mathrm{LR}$ & $9,285.150$ & $8,559.721$ \\
\hline$\chi^{2}$ & $2,536.445$ & $3,261.873$ \\
\hline Degrees of freedom & 14 & 19 \\
\hline
\end{tabular}

Dependent variable: presence of commercial banking ties $(N=13,044)$. One-tailed tests for main variables; two tailed test for control variables. Standard errors are in parentheses; the based model is First FHC. $* p<0.1$

$* * p<0.05$

$* * * p<0.01$

$* * * * p<0.001$ 
Table 5 Logistic regression: Asset management subsidiaries of FHCs.

\begin{tabular}{|c|c|c|}
\hline & Model 1 & Model 2 \\
\hline Embedded ties & & $\begin{array}{l}0.249 * * * * \\
(0.034)\end{array}$ \\
\hline Underwriting ties & & $\begin{array}{l}0.249 \\
(0.240)\end{array}$ \\
\hline Commercial banking ties & & $\begin{array}{l}-0.008 \\
(0.017)\end{array}$ \\
\hline Commercial banking ties squared & & $\begin{array}{l}0.000 \\
(0.000)\end{array}$ \\
\hline Asset management ties squared & & $\begin{array}{l}-0.003^{* * * * *} \\
(0.001)\end{array}$ \\
\hline Customer's experience & $\begin{array}{l}0.817 * * * * \\
(0.041)\end{array}$ & $\begin{array}{l}0.621 * * * * \\
(0.048)\end{array}$ \\
\hline Customer size & $\begin{array}{l}0.471 * * * * \\
(0.050)\end{array}$ & $\begin{array}{l}0.460 * * * * \\
(0.052)\end{array}$ \\
\hline Company age & $\begin{array}{l}0.044 * * * \\
(0.015)\end{array}$ & $\begin{array}{l}-0.041 * * * \\
(0.016)\end{array}$ \\
\hline Intercept & $\begin{array}{l}-10.662 * * * * \\
(0.780)\end{array}$ & $\begin{array}{l}-10.758 * * * * \\
(0.821)\end{array}$ \\
\hline Mega & $\begin{array}{l}-0.217 \\
(0.208)\end{array}$ & $\begin{array}{l}0.303 \\
(0.230)\end{array}$ \\
\hline Hua Nan & $\begin{array}{l}0.000 \\
(0.202)\end{array}$ & $\begin{array}{l}0.158 \\
(0.219)\end{array}$ \\
\hline Fuhwa & $\begin{array}{l}-0.083 * * * * \\
(0.204)\end{array}$ & $\begin{array}{l}0.183 \\
(0.222)\end{array}$ \\
\hline Fubon & $\begin{array}{l}-0.490 * * \\
(0.218)\end{array}$ & $\begin{array}{l}-0.149 \\
(0.234)\end{array}$ \\
\hline E.Sun & $\begin{array}{l}-2,016^{* * * *} \\
(0.304)\end{array}$ & $\begin{array}{l}-1,289 * * * * \\
(0.314)\end{array}$ \\
\hline$-2 \mathrm{LR}$ & $1,818.249$ & $1,736.745$ \\
\hline$\chi^{2}$ & 984.057 & $1,065.741$ \\
\hline Degrees of freedom & 8 & 13 \\
\hline
\end{tabular}

Dependent variable: presence of asset management ties $(N=6,522)$. One-tailed tests for main variables; two tailed tests for control variables. Standard errors are in parentheses; the based model is First FHC. $* p<0.1$

$* * p<0.05$

$* * * p<0.01$

$* * * * p<0.001$

\section{Discussion and conclusion}

\section{Contributions}

In this article, we have investigated and discussed the process, mechanisms, and necessary conditions for effective cross-selling within an FHC and have elaborated on the role of social capital in this inquiry. Contributions to two streams of related literature are made. First, this article contributes to the literature on emerging economies and, in particular, on business groups in Asia. As argued in the institution-based view on diversification, institutional relatedness combined with product relatedness determines the scope of a firm (Peng \& Delios, 2006; Peng et al., 2005). In particular, Peng et al. (2005) articulate how institutional relatedness helps firms in emerging economies capitalize on economies of 
scope based on three non-market forms of capital, i.e., social capital, political capital, and reputational capital. We have extended these works by providing empirical evidence to substantiate the role of social capital - a key construct in institutional relatedness - in creating and sharing customer-specific knowledge; thus, realizing cross-selling opportunities and capitalizing on economies of scope in an emerging economy.

In addition, this article also extends the previous work on business groups in Taiwan. Luo and Chung (2005) study how family and other particularistic ties between top leaders affect business group performance in Taiwan during institutional transition. Also, Chung (2006) reveals that the external ties with government facilitate business group entry into a newly deregulated industry, i.e., banking industry, in Taiwan. Our article extends the argument by explicitly showing how embedded ties with customers, yet another source of social capital, create economies of scope through cross-selling mechanisms for FHCs. Overall, this article validates the importance of informal social structure on the performance of a business group or FHC in an emerging economy.

Second, this article contributes to our understanding of cross-selling within FHCs by investigating the necessary conditions and mechanisms of cross-selling both conceptually and empirically. Previous studies examine the overall synergies of FHCs but find no consistent results (Berger, 2003; Vander Vennet, 2002; Walter, 1997). In particular, this article argues and demonstrates that the major route of cross-selling within an FHC is from the commercial banking division to the underwriting division, answering a key question left in related literature (Jensen, 2003; Kanatas \& Qi; 2003; Rajan, 1996; Yasuda, 2005).

\section{Implications for practice}

This article generates some managerial implications for practice. Traditionally, commercial banking is regarded as a declining industry due to its poor profitability. Scholars report that the relative importance of bank lending as a source of funding for firms is declining (Jensen, 2003; Johnson, 1996). ${ }^{12}$ However, this article suggests that commercial banks are important resource providers and therefore a core player in the informal social network created in FHCs. Due to their continual interactions with customers, commercial banks possess comprehensive and tacit knowledge about their customers that could be shared by other divisions in the FHC, thus creating possibilities of cross-selling. An FHC needs a commercial banking division to provide its knowledge about customers to other divisions.

In Taiwan, FHCs not in possession of competitive commercial banks were searching for opportunities to acquire commercial banks. In 2007, Shin Kong FHC, which did not own commercial banks previously, was acquiring Chang Hwa Bank, a large former state-owned bank. Cathay FHC, whose commercial bank was weak before, acquired a competitive state-owned bank, United World Chinese Commercial Bank. ${ }^{13}$ These

\footnotetext{
12 Alan Greenspan, the chairman of Federal Reserve Board in the U.S. during 1987-2006, also expressed his worry about the impending obsolescence of banks: "Public policy should be concerned with the decline in the importance of banking... The issues are too important for the future growth of our economy and the welfare of our citizens."

${ }^{13}$ Indeed, the first merger approved under the Gramm-Leach-Bliley Act was the acquisition by a security firm, Charles Schwab, of a commercial bank, U.S. Trust Corp.
} 
results are consistent with our findings that commercial banks play important roles as resource providers in FHCs. Our results are also consistent with Macey's (2000) arguments that banks play a unique role in developing relational contracts with borrowers in the economy that cannot be substituted by security markets.

\section{Limitation and future directions}

There are some suggested extensions for future research. In addition to the relational embeddedness factors such as embedded ties, other factors such as structural embeddedness and cognitive embeddedness (Nahapiet \& Ghoshal, 1998) may deserve more thorough examination to explore their roles and functions in the process of cross-selling within an FHC. Further, the sample used in this paper includes only corporate customers, and exploration extended to individual customers segment may be valuable and worthwhile.

\section{Conclusion}

In conclusion, we find that embedded ties and social capital are critical to the process of cross-selling within an FHC in Taiwan. In addition, serving as the key resource or social capital provider in an FHC, the commercial banking division is strategically important and indispensable for cross-selling. These findings may have significant implications not only for Taiwan but also for other emerging economies whose capital markets face similar conditions.

\section{References}

Adler, P. S., \& Kwon, S. 2002. Social capital: Prospects for a new concept. Academy of Management Review, 27(1): 17-40.

Agarwal, R., \& Elston, J. 2001. Bank-firm relationships, financing and firm performance in Germany. Economics Letters, 72: 225-232.

Benston, G. 1996. The origin and justification for the Glass-Steagall Act. In A. Saunders \& I. Walter (Eds.), Universal banking: Financial system design reconsidered: 31-69. Chicago: Irwin.

Berger, A. 2003. The efficiency effects of a single market for financial services in Europe. European Journal of Operational Research, 150: 466-481.

Chung, H. 2006. Managerial ties, control and deregulation: An investigation of business groups entering the deregulated banking industry in Taiwan. Asia Pacific Journal of Management, 23: 505-520.

Chung, S., Singh, H., \& Lee, K. 2000. Complementarity, status similarity, and social capital as drivers of alliance formation. Strategic Management Journal, 21: 1-22.

Cohen, W. M., \& Levinthal, D. A. 1990. Absorptive capacity: A new perspective on learning and innovation. Administrative Science Quarterly, 35: 128-152.

Coleman, J. 1988. Social capital in creation of human capital. American Journal of Sociology, S: 95-120.

Currall, S. C., \& Inkpen, A. C. 2002. A multilevel approach to trust in joint ventures. Journal of International Business Studies, 33(3): 479-495.

Fabozzi, F. J., \& Modigliani, F. 2003. Capital market: Institutions and instruments (3rd ed.). New Jersey: Prentice Hall.

Gorton, G., \& Schmid, F. 2000. Universal banking and the performance of German firms. Journal of Financial Economics, 58: 29-80.

Grant, R. 1996. Toward a knowledge-based theory of the firm. Strategic Management Journal, 17: 109122 (special issue). 
Greene, W. H. 2000. Econometric analysis (4th ed.). New Jersey: Prentice-Hall.

Gulati, R. 1995. Social structure and alliance formation pattern: A longitudinal analysis. Administrative Science Quarterly, 40: 619-652.

Gulati, R., \& Gargiulo, M. 1999. Where do interorganizational networks come from? American Journal of Sociology, 104(5): 1439-1493.

Hamilton, G. G. 1997. Organization and market processes in Taiwan's capitalist economy. In M. Orrù, N. W. Biggart \& G. G. Hamilton (Eds.). The economic organization of East Asian capitalism. Thousand Oaks, CA: Sage.

Hoshi, T. 1996. Back to the future: Universal banking in Japan. In A. Saunders \& I. Walter (Eds.). Universal banking: Financial system design reconsidered: 205-244. Chicago: Irwin.

Hoskisson, R., Eden, L., Lau, C., \& Wright, M. 2000. Strategy in emerging economies. Academy of Management Journal, 43(3): 249-267.

Jensen, M. 2003. The role of network resources in market entry: Commercial banks' entry into investment banking, 1991-1997. Administrative Science Quarterly, 48: 466-497.

Johnson, H. 1996 The banker's guide to investment banker: Securities and underwriting activities in commercial Banking. Chicago: Irwin.

Kanatas, G., \& Qi, J. 2003. Integration of lending and underwriting: Implications of scope economies. The Journal of Finance, 58(3): 1167-1191.

Khanna, T., \& Palepu, K. 1997. Why focus strategy may be wrong for emerging markets? Harvard Business Review, 77(4): 125-134.

Khanna, T., \& Palepu, K. 1999. The right way to restructure conglomerates in emerging markets. Harvard Business Review, 77(4): 125-134.

Khanna, T., \& Palepu, K. 2000. The future of business groups in emerging economies: Long-run evidence from Chile. Academy of Management Journal, 43: 268-285.

Kogut, B., \& Zander, U. 1993. Knowledge of the firm and the evolutionary theory of the multinational corporation. Journal of International Business Studies, 4: 625-645.

Kotabe, M., Martin, X., \& Domoto, H. 2003. Gaining from vertical partnerships: Knowledge transfer, relationship duration, and supplier performance improvement in the U.S. and Japanese automotive industries. Strategic Management Journal, 24: 293-316.

Kroszner, R. 1996. The evolution of universal banking and its regulation in twentieth century America. In A. Saunders \& I. Walter (Eds.), Universal banking: Financial system design reconsidered: 70-100. Chicago: Irwin.

Kroszner, R., \& Rajan, R. 1994. Is the Glass-Steagall Act justified? A study of the U.S. experience with universal banking before 1933. American Economic Review, 84: 810-832.

Kroszner, R., \& Rajan, R. 1997. Organization structure and credibility: Evidence from commercial bank securities activities before the Glass-Steagall Act. Journal of Monetary Economics, 39: 475-516.

Le, N., Venkatesh, S., \& Nguyen, T. 2006. Getting bank financing: A study of Vietnamese private firms. Asia Pacific Journal of Management, 23: 209-227.

Lincoln, J. R. 1984. Analyzing relations in dyads: Problems, models, and an application to interorganizational research. Sociological Methods and Research, 13(1): 45-76.

Luo, X., \& Chung, C. 2005. Keeping it all in the family: The role of particularistic relationships in business group performance during institutional transition. Administrative Science Quarterly, 50: 404-439.

Macey, J. 2000. The business of banking: Before and after Gramm-Leach-Bliley. Journal of Corporation Law, 24(4): 691-722.

McEvily, B., \& Marcus, A. 2005. Embedded ties and the acquisition of competitive capabilities. Strategic Management Journal, 26: 1033-1055.

Nahapiet, J., \& Ghoshal, S. 1998. Social capital, intellectual capital, and organizational advantage. Academy of Management Review, 23(2): 242-266.

Nonaka, I., \& Takeuchi, H. 1994. The knowledge creating company. London: Oxford University Press.

Peng, M. W. 2003. Institutional transition and strategic choice. Academy of Management Review, 28(2): 275-286.

Peng, M. W., \& Delios, A. 2006. What determines the scope of the firm over time and around the world? An Asia Pacific perspective. Asia Pacific Journal of Management, 23: 385-405.

Peng, M. W., \& Heath, P. 1996. The growth of the firm in planned economies in transition: Institutions, organizations, and strategic choice. Academy of Management Review, 21: 492-528.

Peng, M. W., Lee, S., \& Wang, D. 2005. What determines the scope of the firm over time? A focus on institutional relatedness. Academy of Management Review, 30(3): 622-633.

Peng, M. W., \& Luo, Y. 2000. Managerial ties and firm performance in a transition economy: The nature of a micro-macro link. Academy of Management Journal, 43: 486-501. 
Peng, M. W., \& Zhou, J. 2005. How network strategies and institutional transitions evolve in Asia. Asia Pacific Journal of Management, 22: 321-336.

Pfeffer, J., \& Salancik, G. 1978. The external control of organizations. New York: Harper \& Row.

Pollock, T., Porac, J., \& Wade, J. 2004. Constructing deal networks: Brokers as network "architects" in the U.S. IPO market and other examples. Academy of Management Review, 19(1): 50-72.

Rajan, R. 1996. The entry of commercial banks into the securities business: A selective survey of theories and evidence. In A. Saunders \& I. Walter (Eds.), Universal banking: Financial system design reconsidered: 282-302, Chicago: Irwin.

Saunders, A., \& Walter, I. 1994. Universal banking in the United States. London: Oxford University Press.

Tanriverdi, H., \& Venkatraman, N. 2005. Knowledge relatedness and the performance of multibusiness firms. Strategic Management Journal, 26: 97-119.

Teece, D. 1982. Towards an economic theory of multiproduct firm. Journal of Economic Behavior and Organization, 3: 39-63.

Tsai, W. 2001. Knowledge transfer in intraorganizational networks: Effects of network position and absorptive capacity on business unit innovation and performance. Academy of Management Journal, 44(5): 996-1004.

Uzzi, B. 1996. The sources and consequences of embeddedness for the economic performance of organization. American Sociological Review, 61: 674-698

Uzzi, B. 1997. Social structure and competition in interfirm networks: The paradox of embeddedness. Administrative Science Quarterly, 42: 35-67.

Uzzi, B. 1999. Embeddedness in the making of financial capital: How social relations and networks benefit firms seeking financing. American Sociological Review, 64: 481-505.

Vander Vennet, R. 2002. Cost and profit efficiency of financial conglomerates and universal banks in Europe. Journal of Money, Credit, and Banking, 34(1): 254-282.

Walter, I. 1997. Universal banking: A shareholder value perspective. European Management Journal, 15(4): $344-360$.

Williamson, O. 1975. Market and hierarchies: Analysis and antitrust implication. New York: The Free Press.

Williamson, O. 1985. The economic institutions of capitalism. U.S.: The Free Press.

Yasuda, A. 2005. Do bank relationships affect the firm's underwriter choice in the corporate-bond underwriting market? The Journal of Finance, 60(3): 1259-1292.

Yeung, H. W. C. 2006. Change and continuity in Southeast Asian ethnic Chinese business. Asia Pacific Journal of Management, 23: 229-254.

Zucker, L. G. 1986. Production of trust: Institutional sources of economic structure. In B. M. Staw \& L. L. Cummins (Eds.), Research in organizational behavior, 8: 53-112.

Cheng-Min Chuang (PhD, University of Washington) is Professor of International Business at National Taiwan University. His research interests include international joint venture and cooperation, organization and coordination in multinational enterprise, knowledge transfer, and the internationalization of service industries, particularly in the contexts of Taiwan and other Asia Pacific areas.

Chih-Pin Lin (PhD, National Taiwan University) is Assistant Professor at the Department of Business Administration, Aletheia University, Taiwan. His research focuses on the strategic alliance and the management of financial institutions and manufacturing firms in Taiwan. He is also interested in knowledge management in multinational enterprises. 